\title{
Assessment of patient-reported outcome measures in the surgical treatment of patients with gastric cancer
}

\author{
Jennifer Straatman ${ }^{1} \cdot$ Nicole van der Wielen ${ }^{1} \cdot$ Pieter J. Joosten $^{1} \cdot$ \\ Caroline B. Terwee ${ }^{2} \cdot$ Miguel A. Cuesta $^{1} \cdot$ Elise P. Jansma $^{3} \cdot$ Donald L. van der Peet $^{1}$
}

Received: 4 May 2015/Accepted: 6 July 2015/Published online: 27 August 2015

(c) The Author(s) 2015. This article is published with open access at Springerlink.com

\begin{abstract}
Background Gastric cancer is responsible for $10 \%$ of all cancer-related deaths worldwide. With improved operative techniques and neo-adjuvant therapy, survival rates are increasing. Outcomes of interest are shifting to quality of life (QOL), with many different tools available. The aim of this study was to assess which patient-reported outcome measures (PROMs) are used to measure QOL after a gastrectomy for cancer.

Methods A comprehensive search was conducted for original articles investigating QOL after gastrectomy. Two authors independently selected relevant articles, conducted clinical appraisal and extracted data (P.J. and J.S.).

Results Out of 3414 articles, 26 studies were included, including a total of 4690 patients. These studies included ten different PROMs, which could be divided into generic, symptom-specific and disease-specific questionnaires. The EORTC and the FACT questionnaires use an oncological overall QOL module and an organ-specific module. Only one validation study regarding the use of the EORTC after surgery for gastric cancer was available, demonstrating good psychometric properties and clinical validity.

Conclusions A great variety of PROMs are being used in the measurement of QOL after surgery for gastric cancer. A
\end{abstract}

Jennifer Straatman

je.straatman@vumc.nl

1 Department of Gastrointestinal Surgery, VU University Medical Center, De Boelelaan 1117, ZH 7F020,

1081 HV Amsterdam, The Netherlands

2 Department of Epidemiology and Biostatistics, EMGO Institute for Health and Care Research, VU University Medical Center, Amsterdam, The Netherlands

3 Medical Library, VU University Medical Center, Amsterdam, The Netherlands questionnaire with a general module along with a diseasespecific module for the assessment of QOL seems most desirable, such as the EORTC and the FACT with their specific modules. Both are developed in different treatment modalities, such as in surgical patients. EORTC is the most widely used questionnaire and therefore allows for comparison of new studies to existing data. Future studies are needed to assess content validity in surgical gastric cancer patients.

Keywords Quality of life - Gastric cancer - Gastrectomy · PROMs

Gastric cancer is responsible for $10 \%$ of all cancer-related deaths worldwide, with the highest incidences in Eastern Asia, Eastern Europe and South America [1]. Although multiple treatment modalities exist, surgical resection of the primary tumour and regional lymph nodes is still the only curative treatment available for gastric cancer [2]. Currently, the 5-year survival rate after oesophageal resection is approximately $20 \%$ [3]. With the implementation of minimally invasive techniques and additional treatments such as neo-adjuvant chemotherapy, survival rates have improved and an according number of long-term survivors exists [4-6]. Laparoscopic techniques have been shown to improve quality of life sooner after surgery [7].

With increasing survival and decreased morbidity, a shift in interest of outcome parameters is seen from survival and morbidity rates to the impact of radical gastrectomy and chemoradiotherapy on patient-reported outcomes, such as quality of life (QOL) [8]. Information about QOL outcomes should be an important outcome parameter in research regarding the optimal treatment for gastric cancer.

The World Health Organization (WHO) defined QOL as an individuals' perception of their position in life in the 
Fig. 1 Flow chart for the selection of articles for systematic review

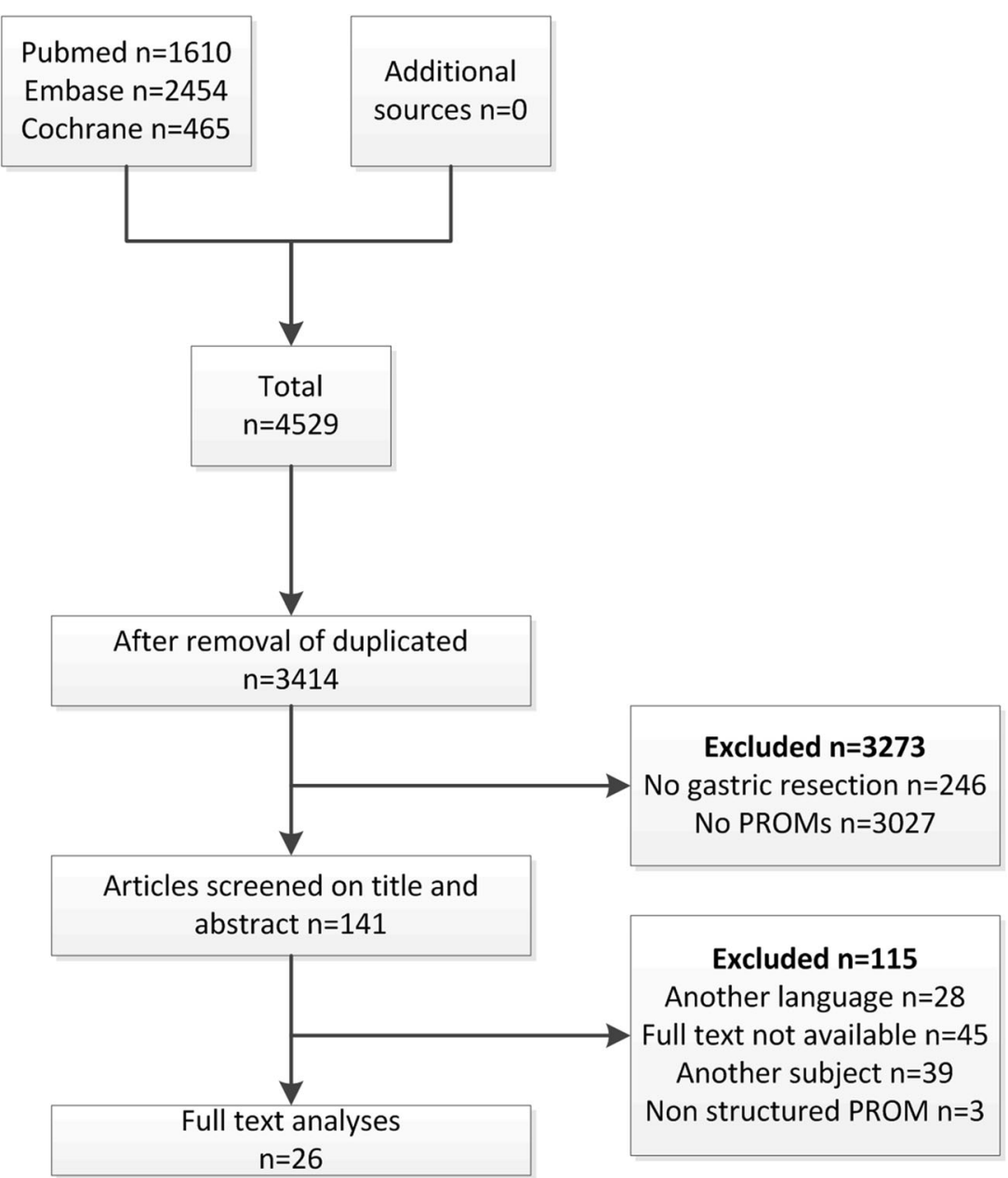

cultural context and in the value system in which they live and in relation to their goals, expectations, standards and concerns [9]. QOL data provide direct measures of benefit as perceived by the patient and may be useful in clarifying treatment preferences. Many different questionnaires are available, both validated and non-validated, to assess the quality of life [7]. Although the different instruments focus on different aspects of QOL, no consensus exists as to which instrument is optimal in the assessment of QOL after gastrectomy for gastric cancer [10]. The aim of this systematic review was to assess which PROMs are used in the assessment of QOL after surgery for gastric cancer.

\section{Materials and methods}

\section{Literature search}

To identify all relevant publications, a systematic search in the bibliographic databases PubMed, EMBASE and The
Cochrane Library (via Wiley) from inception to 14 October 2014 was performed. Search terms included controlled terms from MeSH in PubMed, Emtree in EMBASE.com as well as free text terms. Free text terms were only used in The Cochrane library. Search terms expressing "stomach neoplasm" were used in combination with search terms comprising "surgery". Moreover, an extensive search filter for finding patient-reported outcome measures was used, developed by the University of Oxford ("Appendix"). The reference list of included articles was hand-searched for relevant publications.

\section{Selection criteria and definitions}

Two authors (P.J. and J.S.) independently evaluated the search findings for potential eligibility for systematic review using the MEDLINE, EMBASE and Cochrane databases. The inclusion criteria were: (1) article published in English language; (2) only full-text articles, no abstracts or case reports were included and (3) the study had to investigate 
Table 1 Description of prospective cohort studies

\begin{tabular}{|c|c|c|c|c|c|c|}
\hline Study & Country & Study type & Patient $(n)$ & Aim & QOL instruments & Follow-up \\
\hline Zieren et al. [31] & Germany & Prospective & 106 & $\begin{array}{l}\text { Long-term follow-up after } \\
\text { gastrectomy }\end{array}$ & $\begin{array}{l}\text { EORTC QLQ- } \\
\text { C36 Spitzer } \\
\text { index }\end{array}$ & 12 months \\
\hline Wu et al. [12] & Taiwan & Prospective, RCT & 214 & $\begin{array}{l}\text { D1 versus D3 } \\
\text { lymphadenectomy }\end{array}$ & Spitzer index & $\begin{array}{l}\text { Baseline, } 6,12, \\
24,36,48 \text { and } \\
60 \text { months }\end{array}$ \\
\hline Avery et al. [32] & UK & Prospective & 58 & $\begin{array}{l}\text { QOL in patients that died } \\
\text { within } 2 \text { years versus } \\
\text { survivors }\end{array}$ & $\begin{array}{r}\text { EORTC QLQ- } \\
\text { C30 EORTC } \\
\text { QLQ-STO22 }\end{array}$ & $\begin{array}{l}\text { Baseline, } 3,6,9, \\
\text { and } 12,18 \text { and } \\
24 \text { months }\end{array}$ \\
\hline Svedlund et al. [17] & Sweden & Prospective, RCT & 64 & $\begin{array}{l}\text { Total or subtotal } \\
\text { gastrectomy, with or } \\
\text { without pouch } \\
\text { reconstruction }\end{array}$ & $\begin{array}{l}\text { GSRS } \\
\text { SIP }\end{array}$ & $\begin{array}{l}\text { Baseline, } 3,12, \\
24,36,48 \text { and } \\
60 \text { months }\end{array}$ \\
\hline Karanicolas et al. [33] & USA & Prospective & 134 & $\begin{array}{l}\text { Total, distal or proximal } \\
\text { gastrectomy }\end{array}$ & $\begin{array}{r}\text { EORTC QLQ- } \\
\text { C30 EORTC } \\
\text { QLQ-STO22 }\end{array}$ & $\begin{array}{c}\text { Baseline, } 3,6,9, \\
12,18 \text { months }\end{array}$ \\
\hline Munene et al. [21] & Canada & Prospective & 43 & $\begin{array}{l}\text { Partial versus total } \\
\text { gastrectomy }\end{array}$ & $\begin{array}{l}\text { FACT-G } \\
\text { FACT-GA }\end{array}$ & $\begin{array}{l}\text { Baseline, every } \\
3 \text { months in } \\
2 \text { years }\end{array}$ \\
\hline Kim et al. [34] & Korea & Prospective & 465 & $\begin{array}{l}\text { Total versus subtotal } \\
\text { gastrectomy }\end{array}$ & $\begin{array}{r}\text { EORTC QLQ- } \\
\text { C30 EORTC } \\
\text { QLQ-STO22 }\end{array}$ & $\begin{array}{l}\text { Baseline, } 3 \text { and } \\
12 \text { months }\end{array}$ \\
\hline Takiguchi et al. [29] & Japan & Prospective, RCT & 268 & $\begin{array}{l}\text { Roux-en Y versus Billroth I } \\
\text { reconstruction }\end{array}$ & $\begin{array}{l}\text { EORTC QLQ- } \\
\text { C30 DAUGS20 }\end{array}$ & $\begin{array}{l}21 \text { months } \\
\text { (range } 3 \text { - 34) }\end{array}$ \\
\hline Kono et al. [18] & Japan & Prospective, RCT & 47 & $\begin{array}{l}\text { Roux-en Y versus pouch } \\
\text { reconstruction }\end{array}$ & GSRS & $3,12,48$ months \\
\hline Horvath et al. [16] & Hungary & Prospective, RCT & 46 & $\begin{array}{l}\text { Roux-en Y versus pouch } \\
\text { reconstruction }\end{array}$ & GIQLI & $\begin{array}{l}\text { 6, } 12 \text { and } \\
24 \text { months }\end{array}$ \\
\hline Scurtu et al. [25] & Romania & Prospective & 39 & $\begin{array}{l}\text { Total gastrectomy with E-E } \\
\text { versus E-S anastomosis }\end{array}$ & Korenaga score & 3 and 12 months \\
\hline Kim et al. [35] & Korea & Prospective, RCT & 164 & $\begin{array}{l}\text { Open versus laparoscopy- } \\
\text { assisted distal } \\
\text { gastrectomy }\end{array}$ & $\begin{array}{r}\text { EORTC QLQ- } \\
\text { C30 EORTC } \\
\text { QLQ-STO22 }\end{array}$ & $\begin{array}{r}\text { Baseline, } 1,3,6 \\
\text { and } 12 \text { months }\end{array}$ \\
\hline
\end{tabular}

QOL after gastric resection using questionnaires (i.e. nonstructured interviews were not included). (4) Only patients with gastric carcinoma were included. Studies that described gastrointestinal stromal tumours (GIST) and benign tumours were excluded. Distal, proximal, subtotal and total gastrectomies were included. Wedge resections and local resections were excluded. Regarding surgical techniques, both open and minimally invasive procedures were included, and various reconstructive methods were included (i.e. Roux-en Y or Billroth reconstruction).

\section{Data extraction and quality assessment}

The reviewers (P.J. and J.S.) extracted the following data from each study: first author, title of the article, year of publication, type of study, type of gastrectomy, type of reconstruction, number of patients included and the PROMs used to assess QOL. All articles that were deemed suitable after fulltext analysis were assessed for quality of the performed study.

\section{Results}

\section{Study selection}

Initially, the literature search of MEDLINE, EMBASE and Cochrane resulted in 4529 hits, after removal of duplicates 3414 hits remained. The articles were screened based on title and abstract by two different authors (P.J. and J.S.) independently, and this resulted in a selection of 141 articles for full-text analysis. Of these 141 articles, another 115 were excluded since they did not meet the predefined criteria as described in the methods section; 28 articles were published in another language than English; 45 references consisted only of conference abstracts; 39 articles included a different subject; a final three articles were excluded because they did not use questionnaires but self-reported interviews for QOL assessment. Twenty-six articles remained for further analysis. A flow chart of the article selection is depicted in Fig. 1. 
Table 2 Description of retrospective cohort studies

\begin{tabular}{|c|c|c|c|c|c|c|}
\hline Study & Country & Study type & Patient $(n)$ & Aim & QOL instruments & Follow-up \\
\hline Amemiya et al. [36] & Japan & Retrospective & 223 & $\begin{array}{l}\text { Patients older than } \\
75 \text { years }\end{array}$ & $\begin{array}{l}\mathrm{SF}-12 \\
\text { EQ-5D }\end{array}$ & $\begin{array}{l}\text { Baseline, } 1,3 \text { and } \\
6 \text { months }\end{array}$ \\
\hline Rausei et al. [37] & Italy & Retrospective & 103 & $\begin{array}{l}\text { Total versus subtotal } \\
\text { resection, } \\
\text { lymphadenectomy and } \\
\text { multivisceral resection }\end{array}$ & $\begin{array}{l}\text { EORTC QLQ-C30 } \\
\text { EORTC QLQ- } \\
\text { STO22 }\end{array}$ & $\begin{array}{l}\text { Mean follow-up } \\
81 \pm 80.7 \text { months }\end{array}$ \\
\hline Park et al. [38] & Korea & Retrospective & 275 & $\begin{array}{l}\text { Total versus subtotal/ } \\
\text { distal resection }\end{array}$ & $\begin{array}{l}\text { EORTC QLQ-C30 } \\
\text { EORTC QLQ- } \\
\text { STO22 }\end{array}$ & $\begin{array}{c}\text { Baseline, } 3,6,9,12, \\
18 \text { and } 24 \text { months }\end{array}$ \\
\hline Díaz de Liaño et al. [39] & Spain & Retrospective & 54 & $\begin{array}{l}\text { Total versus subtotal } \\
\text { gastrectomy and D1 } \\
\text { versus D2 } \\
\text { lymphadenectomy }\end{array}$ & EORTC QLQ-C30 & $\begin{array}{l}49 \text { months (range } \\
41-89 \text { ) }\end{array}$ \\
\hline Buhl et al. [40] & Germany & Retrospective & 104 & $\begin{array}{l}\text { Distal versus total } \\
\text { gastrectomy with } \\
\text { Roux-en Y or pouch }\end{array}$ & Spitzer index & 12 months \\
\hline Bae et al. [41] & Korea & Retrospective & 391 & Total versus subtotal & $\begin{array}{l}\text { EORTC QLQ-C30 } \\
\text { EORTC QLQ- } \\
\text { STO22 }\end{array}$ & $27.5 \pm 3.3$ months \\
\hline Huang et al. [42] & Taiwan & Retrospective & 51 & $\begin{array}{l}\text { Total versus subtotal } \\
\text { gastrectomy, early } \\
\text { versus late stage }\end{array}$ & $\begin{array}{l}\text { EORTC QLQ-C30 } \\
\text { EORTC QLQ- } \\
\text { STO22 }\end{array}$ & $\begin{array}{l}17 \text { months (range } \\
6-24 \text { months) }\end{array}$ \\
\hline Soo Lee et al. [43] & Korea & Retrospective & 80 & $\begin{array}{l}\text { Open versus } \\
\text { laparoscopy-assisted } \\
\text { distal gastrectomy }\end{array}$ & $\begin{array}{l}\text { EORTC QLQ-C30 } \\
\text { EORTC QLQ- } \\
\text { STO22 }\end{array}$ & $\begin{array}{l}6 \text { months to } 5 \text { year } \\
\text { range }\end{array}$ \\
\hline Tyrvainen et al. [44] & Finland & Retrospective & 172 & $\begin{array}{l}\text { QOL in long-term } \\
\text { survivors after total } \\
\text { gastrectomy }\end{array}$ & $\begin{array}{l}\mathrm{SF}-36 \\
15 \mathrm{D}\end{array}$ & Median 9 (6-19) years \\
\hline Nakamura et al. [11] & Japan & Retrospective & 883 & $\begin{array}{l}\text { Development and } \\
\text { validation of DAUGS }\end{array}$ & DAUGS20 & $\begin{array}{l}3 \text { and } 6 \text { months, } 1,2 \\
\text { and } 3 \text { years }\end{array}$ \\
\hline Nakamura et al. [45] & Japan & Retrospective & 165 & $\begin{array}{l}\text { Evaluate DAUGS in } \\
\text { patients after gastric } \\
\text { resection }\end{array}$ & DAUGS32 & $\begin{array}{l}3-6 \text { months, } 6-1 \text { year, } \\
1-2 \text { years, } 1-3 \text { years }\end{array}$ \\
\hline Kong et al. [46] & Korea & Retrospective & 272 & $\begin{array}{l}\text { Chronological change } \\
\text { of QOL after } \\
\text { gastrectomy }\end{array}$ & $\begin{array}{l}\text { EORTC QLQ-C30 } \\
\text { EORTC QLQ-STO22 }\end{array}$ & $\begin{array}{l}\text { Baseline, 3, 6, } 9 \text { and } \\
12 \text { months }\end{array}$ \\
\hline Soo Lee et al. [47] & Korea & Retrospective & 143 & $\begin{array}{l}\text { QOL } 5 \text { years or more } \\
\text { after total gastrectomy }\end{array}$ & $\begin{array}{l}\text { EORTC QLQ-C30 } \\
\text { EORTC QLQ-STO22 }\end{array}$ & $\begin{array}{l}\text { Mean } 89.3 \text { (range } \\
66-201 \text { ) months }\end{array}$ \\
\hline Soo Lee et al. [48] & Korea & Retrospective & 126 & $\begin{array}{l}\text { QOL of long-term } \\
\text { survivors after distal } \\
\text { subtotal gastrectomy }\end{array}$ & $\begin{array}{l}\text { EORTC QLQ-C30 } \\
\text { EORTC QLQ-STO22 }\end{array}$ & 5 years \\
\hline
\end{tabular}

\section{Study characteristics}

Twenty-six articles were included for full-text analysis, of which twelve articles were prospective cohort studies, six of which were randomized controlled trials, and fourteen were retrospective cohort studies with prospective QOL assessment, including a total of 4690 patients. One study was a development and validation study [11]. There was great dispersion in follow-up data, ranging from 6 months to 5 years. An overview of the included articles is given in Table 1 for prospective articles and Table 2 for retrospective studies.

\section{The quality-of-life instruments}

Twenty-six full-text articles were assessed regarding QOL following surgical procedures for gastric cancer. In these articles, a total of ten different PROMs were described. Different instruments focussed on different dimensions of the QOL (i.e. physical, functional, social and emotional function).

The PROMs could be divided into separate categories, as given in Table 3. First four generic instruments were used, i.e. the Short Form-12 (SF-12), Sickness Impact Profile (SIP), Spitzer index and EuroQol-5D (EQ-5D). These instruments were used to compare results across 
Table 3 Description of patient-reported outcome measures (PROMs)

\begin{tabular}{|c|c|c|c|c|c|}
\hline & Questionnaires & Target population & $\begin{array}{l}\text { Dimensions } \\
\text { (number of } \\
\text { items) }\end{array}$ & $\begin{array}{l}\text { Ease of scoring and } \\
\text { administration } \\
\text { (range of scores) }\end{array}$ & $\begin{array}{l}\text { Number } \\
\text { of } \\
\text { studies }\end{array}$ \\
\hline \multirow[t]{4}{*}{ Generic } & SIP [49] & $\begin{array}{l}\text { Very broad, tested in non-, } \\
\text { in- and out-patient with } \\
\text { different illnesses and } \\
\text { different severities }\end{array}$ & $\begin{array}{l}\text { Sleep and rest (7) } \\
\text { Eating (9) } \\
\text { Work (9) } \\
\text { Home management (10) } \\
\text { Recreation and pastimes (8) } \\
\text { Ambulation (10) } \\
\text { Mobility (10) } \\
\text { Body care and movement (23) } \\
\text { Social interaction (20) } \\
\text { Alertness behaviour (10) } \\
\text { Emotional behaviour (9) } \\
\text { Communication (9) } \\
\text { Total = 136 }\end{array}$ & Easy (0-136) & 1 \\
\hline & SF-12 [50] & General population & $\begin{array}{l}\text { Physical functioning (2) } \\
\text { Role physical (2) } \\
\text { Bodily pain (1) } \\
\text { General health (1) } \\
\text { Vitality (1) } \\
\text { Social functioning (1) } \\
\text { Role emotional (2) } \\
\text { Mental health (2) }\end{array}$ & Easy (12-47) & 1 \\
\hline & EQ-5D [51] & General population & $\begin{array}{l}\text { Mobility } \\
\text { Self-care } \\
\text { Usual activities } \\
\text { Pain/discomfort } \\
\text { Anxiety/depression }\end{array}$ & $\begin{array}{l}\text { Easy }(0-100 \text { per } \\
\text { dimension) }\end{array}$ & 1 \\
\hline & $\begin{array}{l}\text { The Spitzer QOL } \\
\text { index [13] }\end{array}$ & Cancer patients & $\begin{array}{l}\text { Activity } \\
\text { Daily living } \\
\text { Health } \\
\text { Social support } \\
\text { Outlook }\end{array}$ & $\begin{array}{l}\text { Easy }(0-2 \text { per } \\
\text { question) }(0-10)\end{array}$ & 3 \\
\hline \multirow[t]{2}{*}{$\begin{array}{r}\text { Symptom } \\
\text { focused }\end{array}$} & GIQLI [14, 52] & $\begin{array}{l}\text { Developed in patients with } \\
\text { benign or malignant } \\
\text { disorders of the } \\
\text { oesophagus, stomach, } \\
\text { gallbladder, pancreas, } \\
\text { small intestine, colon, and } \\
\text { rectum. And developed in } \\
\text { patients who underwent a } \\
\text { laparoscopic chole- } \\
\text { cystectomy }\end{array}$ & $\begin{array}{l}\text { Physical well-being (10) } \\
\text { Mental well-being (5) } \\
\text { Gastrointestinal symptoms (16) } \\
\text { Single items (5) }\end{array}$ & $\begin{array}{l}\text { Easy }(0-4 \text { per } \\
\text { question) }(0-144)\end{array}$ & 1 \\
\hline & GSRS $[15,53]$ & $\begin{array}{l}\text { Developed for irritable } \\
\text { bowel syndrome and } \\
\text { peptic ulcer disease. Later } \\
\text { validated in upper } \\
\text { gastrointestinal patient }\end{array}$ & $\begin{array}{l}\text { Abdominal pain syndrome } \\
\text { Reflux syndrome } \\
\text { Indigestion syndrome } \\
\text { Diarrhoea syndrome } \\
\text { Constipation syndrome }\end{array}$ & $\begin{array}{l}\text { Easy }(0-3 \text { per } \\
\text { question) }(0-45)\end{array}$ & 2 \\
\hline
\end{tabular}


Table 3 continued

\begin{tabular}{|c|c|c|c|c|c|}
\hline & Questionnaires & Target population & $\begin{array}{l}\text { Dimensions } \\
\text { (number of } \\
\text { items) }\end{array}$ & $\begin{array}{l}\text { Ease of scoring and } \\
\text { administration } \\
\text { (range of scores) }\end{array}$ & $\begin{array}{l}\text { Number } \\
\text { of } \\
\text { studies }\end{array}$ \\
\hline \multirow[t]{2}{*}{ Cancer specific } & $\begin{array}{l}\text { EORTC QLQ-C30 } \\
\text { [22] }\end{array}$ & $\begin{array}{l}\text { Cancer patients (developed } \\
\text { in lung cancer patients) }\end{array}$ & $\begin{array}{l}\text { Global health (2) } \\
\text { Functional scales } \\
\text { Physical (5) } \\
\text { Role (2) } \\
\text { Cognitive (2) } \\
\text { Emotional (4) } \\
\text { Social (2) } \\
\text { Symptom scales } \\
\text { Fatigue (3) } \\
\text { Pain (2) } \\
\text { Nausea and vomiting (2) } \\
\text { Single items (6) }\end{array}$ & $\begin{array}{l}\text { Easy }(1-4 \text { per } \\
\text { question) } \\
(30-120)\end{array}$ & 15 \\
\hline & FACT-G [19] & $\begin{array}{l}\text { General cancer, developed } \\
\text { in breast, lung and } \\
\text { colorectal cancer }\end{array}$ & $\begin{array}{l}\text { Physical (7) } \\
\text { Social/family (7) } \\
\text { Emotional (6) } \\
\text { Functional (7) }\end{array}$ & $\begin{array}{l}\text { Easy }(1-4 \text { per } \\
\text { question }) \\
(0-108)\end{array}$ & 1 \\
\hline \multirow[t]{2}{*}{$\begin{array}{l}\text { Gastric cancer } \\
\text { specific }\end{array}$} & $\begin{array}{l}\text { EORTC QLQ- } \\
\text { STO22 [23] }\end{array}$ & $\begin{array}{l}\text { Patients with gastric cancer } \\
\text { undergoing surgery, } \\
\text { chemo- or } \\
\text { chemoradiotherapy in } \\
\text { curative or palliative } \\
\text { setting }\end{array}$ & $\begin{array}{l}\text { Five scales } \\
\text { Dysphagia (4) } \\
\text { Eating restrictions (5) } \\
\text { Pain (3) } \\
\text { Reflux (3) } \\
\text { Anxiety (3) } \\
\text { Three single items } \\
\text { Dry mouth (1) } \\
\text { Body image (1) } \\
\text { Hair loss (2) }\end{array}$ & $\begin{array}{l}\text { Easy }(1-4 \text { per } \\
\text { question }) \\
(22-88)\end{array}$ & 12 \\
\hline & FACT-Ga [20] & $\begin{array}{l}\text { Gastric cancer } \\
\text { (adenocarcinoma), } \\
\text { gastrectomy, chemo and } \\
\text { radiotherapy }\end{array}$ & Gastric cancer subscale (19) & $\begin{array}{l}\text { Easy }(0-4 \text { per } \\
\text { question) }(0-76)\end{array}$ & 1 \\
\hline \multirow[t]{2}{*}{ Postoperative } & $\begin{array}{l}\text { Korenaga's score } \\
\text { [25] }\end{array}$ & $\begin{array}{l}\text { Treatment-specific after } \\
\text { gastrectomy }\end{array}$ & Single items (14) & $\begin{array}{l}\text { Easy }(0-2 \text { per } \\
\text { question) }(0-28)\end{array}$ & 1 \\
\hline & DAUGS20 [11] & $\begin{array}{l}\text { Developed to assess } \\
\text { postoperative dysfunction } \\
\text { after surgery for gastric } \\
\text { and oesophageal } \\
\text { carcinoma }\end{array}$ & $\begin{array}{l}\text { Single items (20) } \\
\text { Limited activity due to decreased } \\
\text { food consumption } \\
\text { Reflux } \\
\text { Dumping } \\
\text { Nausea and vomiting } \\
\text { Deglutition difficulty } \\
\text { Pain } \\
\text { Difficulty in stool formation and } \\
\text { passage }\end{array}$ & $\begin{array}{l}\text { Easy }(1-5 \text { per } \\
\text { question) }(34-170)\end{array}$ & 2 \\
\hline
\end{tabular}

SIP Sickness Impact Profile, $S F-12$ The 12-item Short Form Healthy Survey, EQ-5D EuroQoL-5D, GIQLI Gastrointestinal Quality of Life Index, GSRS Gastrointestinal Symptom Rating Scale, EORTC QLQ European Organization for Research and Treatment QOL Questionnaire, FACT-G Functional Assessment of Cancer Therapy-General, DAUGS Dysfunction After Upper Gastrointestinal Surgery, FACT-Ga Functional Assessment of Cancer Therapy for patients with Gastric Cancer 
different conditions of health. These questionnaires are developed and validated to measure QOL in a general population. The Spitzer index is a global health assessment tool, which assess activity, daily living, health, support system and outlook. No symptom- or treatment-specific questions are included in this questionnaire [12, 13]. The SF-12, SIP and EQ-5D have all been used once, and three out of the twenty studies have used the Spitzer index.

Secondly, symptom-specific questionnaires were used, namely the Gastrontestinal Quality of Life Index (GIQLI) and the Gastrointestinal Symptom Rating Scale (GSRS). The GIQLI is developed in patients with benign and malignant disorders [14]. The GRSR was initially developed in patients with irritable bowel disease and not specifically designed for oncological or postoperative patients [15]. Only one study assessed QOL with the GIQLI score [16]. The GSRS score was used in two studies and allowed for overall assessment and of assessment of the individual items [17, 18]. GIQLI and GSRS are specifically designed for gastrointestinal symptoms, not for overall QOL.

A third group consists of disease-specific questionnaires. The Functional Assessment of Cancer Therapy (FACT) questionnaires consist of a general health module (FACT$\mathrm{G}$ ), and disease-specific modules can be added, such as FACT-Ga for gastric cancer [19, 20], thus allowing for the assessment of overall QOL and assessment of diseasespecific symptoms by adding the appropriate module. The FACT-Ga is developed in patients with gastric cancer who underwent different treatment modalities, such as gastrectomy, chemotherapy and radiotherapy [20]. One study has used the FACT questionnaire [21].

The European Organisation for Research and Treatment of Cancer (EORTC) questionnaires work in a similar fashion, consisting of a general health questionnaire, the EORTC QLQ-C30, which is aimed specifically at cancer patients [22]. Disease-specific modules can be added, such as the EORTC QLQ-STO22 for gastric cancer. The EORTC QLQ-STO22 is developed in patients with gastric cancer who underwent different treatment modalities, such as surgery, chemo- or chemoradiotherapy in curative or palliative setting $[23,24]$. The EORTC QLQ-STO22 and the FACT-Ga are site-specific questionnaires that are related to gastric cancer [20, 23]. Fifteen out of twenty-six studies have used the EORTC QLQ-C30 of which twelve studies also included the EORTC QLQ-STO22 module.

Only one validation study was identified, which assessed the use of the STO22 module in patients who were operated in curative or palliative setting. The module was found to have a good internal consistency (Crohnbach's alpha's $>0.7$ ) and was deemed reliable and sensitive to changes in both individual patient status and differences between patient groups [23].

Postoperative patients are considered a different entity in the DAUGS20 and Korenaga's score, and these questionnaires focus specifically on patients following gastrectomy for cancer [11]. The questionnaires measure treatment-specific symptoms, such as appetite, swallowing, heartburn and diarrhoea [25, 26]. The Dysfunction After Upper Gastrointestinal Surgery (DAUGS20) questionnaire was originally designed in gastric and oesophageal cancer patients who had undergone surgery. The DAUGS is designed to measure QOL postoperative, and no baseline measurement is included [26]. An overview of the different PROMs is provided in Table 3.

\section{Discussion}

The here-presented systematic review aimed to review what PROMs are available in assessing the QOL in patients with gastric cancer who undergo gastric resection. Ten PROMs were identified in 26 studies regarding different surgical techniques or comparison of different treatment modalities.

Gastrectomy with radical resection margins of $5 \mathrm{~cm}$ around the tumour along with adequate lymfadenectomy is currently the only curative therapy available in gastric cancer [27]. Overall QOL and even separate domains of QOL may differ between different treatment modalities. Question remains whether surgical patients should be considered a separate entity, and whether questionnaires should be developed or adapted for patients undergoing gastrectomy. In an optimal setting, the PROMs should allow for overall assessment of QOL, along with specific modules to assess specific effects associated with the disease and treatment [28].

The DAUGS20 and Korenaga's score consider surgical patients to be a different entity. These questionnaires are specifically aimed at the postoperative patient who had surgery for gastric cancer [25, 29]. No validation studies regarding these questionnaires were available. DAUGS20 and Korenaga's score are not developed for overall QOL assessment and are preferably to be used alongside a general QOL PROM [26, 30]. Since the questionnaires aim specifically at the postoperative patient, they do not allow for comparison of QOL among different treatment modalities such as chemotherapy and radiotherapy. They do allow for comparison of QOL among different surgical techniques.

The EORTC and FACT questionnaires consider gastric cancer patients as a whole. Both the EORTC and FACT questionnaires consist of a general cancer QOL module to which organ-specific module can be added (EORTC QLQSTO22 and FACT-Ga), allowing for general and diseasespecific QOL assessment between different treatment modalities. Both questionnaires were developed in patients with gastric cancer undergoing different treatment modalities, including surgery. With regard to comparability and reproducibility, the EORTC was used more often and 
might therefore allow for comparison to conducted studies, taking into account the heterogeneity in research questions, time points of QOL measurement and follow-up.

Fourteen $(54 \%)$ of the included studies consisted of retrospective cohort studies. Only six randomized studies were available. Differences in study design, endpoints, patient groups, surgical techniques and time points in the studies further limited assessment and pooling of data. No validation studies were available for the use of these PROMs in patients undergoing surgery for gastric cancer; hence, comparison of the performance of the different PROMs with regard to validity, internal consistency and discriminative ability was not possible.

Future research should focus on content validity of the used questionnaires in postgastrectomy patients in order to assess whether all the important domains are truly assessed and no items are missing. In order to further assess the use of PROMs in treatment of individual patients, our project group is currently aiming to develop a core outcome set of patient-reported outcomes in gastric cancer patients.

In conclusion, in the assessment of QOL in surgical gastric cancer patients, a great variety of PROMs are being used. A questionnaire with a general module to assess overall QOL, which can be supplemented with disease-specific modules allowing for the assessment or QOL of different treatment modalities, seems to be most desirable. With regard to current practice, the EORTC QLQ-C30 with STO22 module was developed in gastric cancer patients with different treatments, and it is used most widely, allowing for comparison of new data to studies that were already conducted. Future research should assess the need for treatment-specific modules.

\section{Compliance with ethical standards}

Disclosures The authors, Jennifer Straatman, Nicole van der Wielen, Pieter J. Joosten, Caroline B. Terwee, Miguel A. Cuesta, Elise P. Jansma and Donald L. van der Peet, declare that they have no conflict of interest

Open Access This article is distributed under the terms of the Creative Commons Attribution 4.0 International License (http://crea tivecommons.org/licenses/by/4.0/), which permits unrestricted use, distribution, and reproduction in any medium, provided you give appropriate credit to the original author(s) and the source, provide a link to the Creative Commons license, and indicate if changes were made.

\section{Appendix}

\begin{tabular}{lcc}
\hline Search & PubMed Query 17 November 2014 & $\begin{array}{l}\text { Items } \\
\text { found }\end{array}$ \\
\hline$\# 9$ & 1610 \\
\hline
\end{tabular}

\begin{tabular}{|c|c|c|}
\hline Search & PubMed Query 17 November 2014 & $\begin{array}{l}\text { Items } \\
\text { found }\end{array}$ \\
\hline & 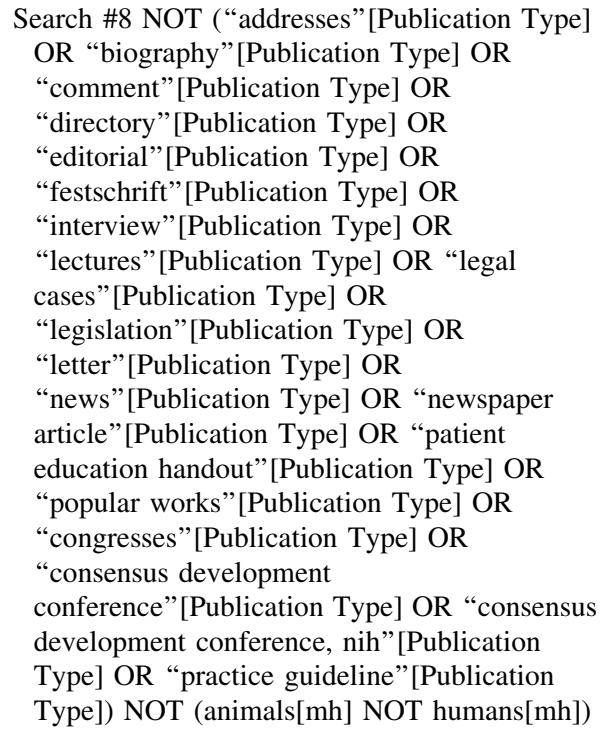 & \\
\hline$\# 8$ & Search \#5 AND \#6 AND \#7 & 1625 \\
\hline \#7 & $\begin{array}{l}\text { Search (HR-PRO[tiab] OR HRPRO[tiab] OR } \\
\text { HRQL[tiab] OR HRQoL[tiab] OR QL[tiab] OR } \\
\text { QoL[tiab] OR quality of life[tiab] OR life } \\
\text { quality[tiab] OR health index*[tiab] OR health } \\
\text { indices[tiab] OR health profile*[tiab] OR } \\
\text { health status[tw] OR ((patient[tiab] OR } \\
\text { self[tiab] OR child[tiab] OR parent[tiab] OR } \\
\text { carer[tiab] OR proxy[tiab]) AND ((report[tiab] } \\
\text { OR reported[tiab] OR reporting[tiab]) OR } \\
\text { (rated[tiab] OR rating[tiab] OR ratings[tiab]) } \\
\text { OR based[tiab] OR (assessed[tiab] OR } \\
\text { assessment[tiab] OR assessments[tiab]))) OR } \\
\text { ((disability[tiab] OR function[tiab] OR } \\
\text { functional[tiab] OR functions[tiab] OR } \\
\text { subjective[tiab] OR utility[tiab] OR } \\
\text { utilities[tiab] OR wellbeing[tiab] OR well } \\
\text { being[tiab]) AND (outcome[tiab] OR } \\
\text { outcomes[tiab] OR index[tiab] OR indices[tiab] } \\
\text { OR instrument[tiab] OR instruments[tiab] OR } \\
\text { measure[tiab] OR measures[tiab] OR } \\
\text { questionnaire[tiab] OR questionnaires[tiab] OR } \\
\text { profile[tiab] OR profiles[tiab] OR scale[tiab] } \\
\text { OR scales[tiab] OR score[tiab] OR scores[tiab] } \\
\text { OR status[tiab] OR survey[tiab] OR } \\
\text { surveys[tiab]))) }\end{array}$ & 1657339 \\
\hline \#6 & $\begin{array}{l}\text { Search "gastrectomy" }[\mathrm{MeSH}] \mathrm{OR} \\
\text { ((gastrectom*[tiab] OR "gastric } \\
\text { resection"[tiab] OR gastrectom*[ot] OR } \\
\text { "gastric resection"[ot]) NOT medline[sb]) }\end{array}$ & 27902 \\
\hline$\# 5$ & $\begin{array}{l}\text { Search “Stomach Neoplasms"[Mesh] OR } \\
\text { Stomach Neoplasm*[tiab] OR Gastric } \\
\text { Neoplasm*[tiab] OR Stomach Cancer*[tiab] } \\
\text { OR Gastric Cancer*[tiab] OR Stomach } \\
\text { carcinoma*[tiab] OR gastric carcinoma*[tiab] } \\
\text { OR stomach tumor*[tiab] OR stomach } \\
\text { tumour*[tiab] OR gastric tumor*[tiab] OR } \\
\text { gastric tumour*[tiab] OR stomach } \\
\text { neoplasia*[tiab] OR cardia carcinoma*[tiab] } \\
\text { OR linitis plastica[tiab] OR Stomach }\end{array}$ & 87062 \\
\hline
\end{tabular}




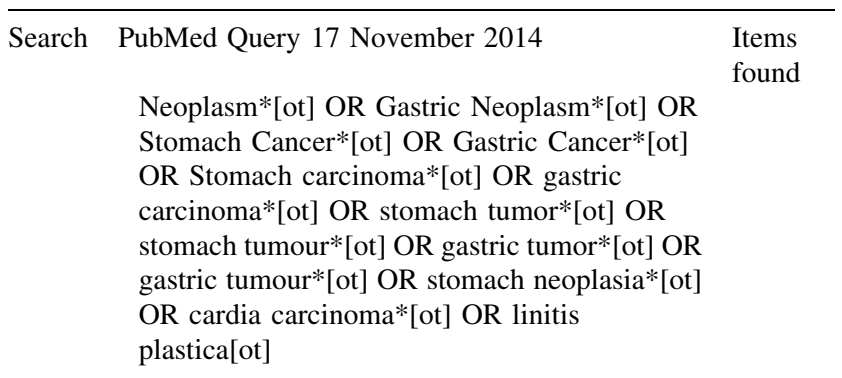

\section{References}

1. Jemal A, Bray F, Center MM, Ferlay J, Ward E, Forman D (2011) Global cancer statistics. CA Cancer J Clin 61:69-90

2. Wu CW, Lo SS, Shen KH, Hsieh MC, Lui WY, P'Eng FK (2000) Surgical mortality, survival, and quality of life after resection for gastric cancer in the elderly. World J Surg 24:465-472

3. Hulscher JB, Tijssen JG, Obertop H, van Lanschot JJ (2001) Transthoracic versus transhiatal resection for carcinoma of the esophagus: a meta-analysis. Ann Thorac Surg 72:306-313

4. Kitano S, Iso Y, Moriyama M, Sugimachi K (1994) Laparoscopyassisted Billroth I gastrectomy. Surg Laparosc Endosc 4:146-148

5. Azagra JS, Goergen M, De Simone P, Ibanez-Aguirre J (1999) Minimally invasive surgery for gastric cancer. Surg Endosc 13:351-357

6. Cunningham D, Allum WH, Stenning SP, Thompson JN, Van de Velde CJ, Nicolson M, Scarffe JH, Lofts FJ, Falk SJ, Iveson TJ, Smith DB, Langley RE, Verma M, Weeden S, Chua YJ (2006) Perioperative chemotherapy versus surgery alone for resectable gastroesophageal cancer. N Engl J Med 355:11-20

7. Korolija D, Sauerland S, Wood-Dauphinee S, Abbou CC, Eypasch E, Caballero MG, Lumsden MA, Millat B, Monson JR, Nilsson G, Pointner R, Schwenk W, Shamiyeh A, Szold A, Targarona E, Ure B, Neugebauer E, European Association for Endoscopic S (2004) Evaluation of quality of life after laparoscopic surgery: evidence-based guidelines of the European Association for Endoscopic Surgery. Surg Endosc 18:879-897

8. Blazeby JM, Avery K, Sprangers M, Pikhart H, Fayers P, Donovan J (2006) Health-related quality of life measurement in randomized clinical trials in surgical oncology. J Clin Oncol 24:3178-3186

9. World Health Organization (1995) The World Health Organization quality of life assessment (WHOQOL): position paper from the World Health Organization. Soc Sci Med 41:1403-1409

10. Conroy T, Marchal F, Blazeby JM (2006) Quality of life in patients with oesophageal and gastric cancer: an overview. Oncology 70:391-402

11. Nakamura M, Hosoya Y, Umeshita K, Yano M, Doki Y, Miyashiro I, Dannoue H, Mori M, Kishi K, Lefor AT (2011) Postoperative quality of life: development and validation of the "Dysfunction After Upper Gastrointestinal Surgery" scoring system. J Am Coll Surg 213:508-514

12. Wu CW, Chiou JM, Ko FS, Lo SS, Chen JH, Lui WY, Whang-Peng J (2008) Quality of life after curative gastrectomy for gastric cancer in a randomised controlled trial. Br J Cancer 98:54-59

13. Spitzer WO, Dobson AJ, Hall J, Chesterman E, Levi J, Shepherd R, Battista RN, Catchlove BR (1981) Measuring the quality of life of cancer patients: a concise QL-index for use by physicians. J Chronic Dis 34:585-597

14. Eypasch E, Williams JI, Wood-Dauphinee S, Ure BM, Schmulling C, Neugebauer E, Troidl H (1995) Gastrointestinal
Quality of Life Index: development, validation and application of a new instrument. Br J Surg 82:216-222

15. Kulich KR, Madisch A, Pacini F, Pique JM, Regula J, Van Rensburg CJ, Ujszaszy L, Carlsson J, Halling K, Wiklund IK (2008) Reliability and validity of the Gastrointestinal Symptom Rating Scale (GSRS) and Quality of Life in Reflux and Dyspepsia (QOLRAD) questionnaire in dyspepsia: a six-country study. Health Qual Life Outcomes 6:12

16. Horvath OP, Kalmar K, Cseke L, Poto L, Zambo K (2001) Nutritional and life-quality consequences of aboral pouch construction after total gastrectomy: a randomized, controlled study. Eur J Surg Oncol 27:558-563

17. Svedlund J, Sullivan M, Liedman B, Lundell L (1999) Long term consequences of gastrectomy for patient's quality of life: the impact of reconstructive techniques. Am J Gastroenterol 94:438-445

18. Kono K, Iizuka H, Sekikawa T, Sugai H, Takahashi A, Fujii H, Matsumoto Y (2003) Improved quality of life with jejunal pouch reconstruction after total gastrectomy. Am J Surg 185:150-154

19. Cella DF, Tulsky DS, Gray G, Sarafian B, Linn E, Bonomi A, Silberman M, Yellen SB, Winicour P, Brannon J et al (1993) The Functional Assessment of Cancer Therapy scale: development and validation of the general measure. J Clin Oncol 11:570-579

20. Garland SN, Pelletier G, Lawe A, Biagioni BJ, Easaw J, Eliasziw M, Cella D, Bathe OF (2011) Prospective evaluation of the reliability, validity, and minimally important difference of the functional assessment of cancer therapy-gastric (FACT-Ga) quality-of-life instrument. Cancer 117:1302-1312

21. Munene G, Francis W, Garland SN, Pelletier G, Mac KLA, Bathe OF (2012) The quality of life trajectory of resected gastric cancer. J Surg Oncol 105:337-341

22. Aaronson NK, Ahmedzai S, Bergman B, Bullinger M, Cull A, Duez NJ, Filiberti A, Flechtner H, Fleishman SB, de Haes JC et al (1993) The European Organization for Research and Treatment of Cancer QLQ-C30: a quality-of-life instrument for use in international clinical trials in oncology. J Natl Cancer Inst 85:365-376

23. Blazeby JM, Conroy T, Bottomley A, Vickery C, Arraras J, Sezer O, Moore J, Koller M, Turhal NS, Stuart R, Van Cutsem E, D'Haese S, Coens C, European Organisation for R, Treatment of Cancer G, Quality of Life G (2004) Clinical and psychometric validation of a questionnaire module, the EORTC QLQ-STO 22, to assess quality of life in patients with gastric cancer. Eur J Cancer 40:2260-2268

24. Vickery CW, Blazeby JM, Conroy T, Arraras J, Sezer O, Koller M, Rosemeyer D, Johnson CD, Alderson D, Group EQoL (2001) Development of an EORTC disease-specific quality of life module for use in patients with gastric cancer. Eur J Cancer 37:966-971

25. Scurtu R, Groza N, Otel O, Goia A, Funariu G (2005) Quality of life in patients with esophagojejunal anastomosis after total gastrectomy for cancer. Rom J Gastroenterol 14:367-372

26. Nakamura M, Kido Y, Yano M, Hosoya Y (2005) Reliability and validity of a new scale to assess postoperative dysfunction after resection of upper gastrointestinal carcinoma. Surg Today 35:535-542

27. Japanese Gastric Cancer Association (2011) Japanese gastric cancer treatment guidelines 2010 (version 3). Gastric Cancer 14:113-123

28. Garcia SF, Cella D, Clauser SB, Flynn KE, Lad T, Lai JS, Reeve BB, Smith AW, Stone AA, Weinfurt K (2007) Standardizing patient-reported outcomes assessment in cancer clinical trials: a patient-reported outcomes measurement information system initiative. J Clin Oncol 25:5106-5112

29. Takiguchi S, Yamamoto K, Hirao M, Imamura H, Fujita J, Yano M, Kobayashi K, Kimura Y, Kurokawa Y, Mori M, Doki Y, 
Osaka University Clinical Research Group for Gastroenterological S (2012) A comparison of postoperative quality of life and dysfunction after Billroth I and Roux-en-Y reconstruction following distal gastrectomy for gastric cancer: results from a multiinstitutional RCT. Gastric Cancer 15:198-205

30. Korenaga D, Orita H, Okuyama T, Moriguchi S, Maehara Y, Sugimachi K (1992) Quality of life after gastrectomy in patients with carcinoma of the stomach. Br J Surg 79:248-250

31. Zieren HU, Zippel K, Zieren J, Muller JM (1998) Quality of life after surgical treatment of gastric carcinoma. Eur J Surg 164:119-125

32. Avery K, Hughes R, McNair A, Alderson D, Barham P, Blazeby J (2010) Health-related quality of life and survival in the 2 years after surgery for gastric cancer. Eur J Surg Oncol 36:148-154

33. Karanicolas PJ, Graham D, Gonen M, Strong VE, Brennan MF, Coit DG (2013) Quality of life after gastrectomy for adenocarcinoma: a prospective cohort study. Ann Surg 257:1039-1046

34. Kim AR, Cho J, Hsu YJ, Choi MG, Noh JH, Sohn TS, Bae JM, Yun YH, Kim S (2012) Changes of quality of life in gastric cancer patients after curative resection: a longitudinal cohort study in Korea. Ann Surg 256:1008-1013

35. Kim YW, Baik YH, Yun YH, Nam BH, Kim DH, Choi IJ, Bae JM (2008) Improved quality of life outcomes after laparoscopyassisted distal gastrectomy for early gastric cancer: results of a prospective randomized clinical trial. Ann Surg 248:721-727

36. Amemiya T, Oda K, Ando M, Kawamura T, Kitagawa Y, Okawa Y, Yasui A, Ike H, Shimada H, Kuroiwa K, Nimura Y, Fukata S (2007) Activities of daily living and quality of life of elderly patients after elective surgery for gastric and colorectal cancers. Ann Surg 246:222-228

37. Rausei S, Mangano A, Galli F, Rovera F, Boni L, Dionigi G, Dionigi R (2013) Quality of life after gastrectomy for cancer evaluated via the EORTC QLQ-C30 and QLQ-STO22 questionnaires: surgical considerations from the analysis of 103 patients. Int J Surg (London, England) 11(Suppl 1):S104-S109

38. Park S, Chung HY, Lee SS, Kwon O, Yu W (2014) Serial comparisons of quality of life after distal subtotal or total gastrectomy: what are the rational approaches for quality of life management? J Gastric Cancer 14:32-38

39. Diaz De Liano A, Oteiza Martinez F, Ciga MA, Aizcorbe M, Cobo F, Trujillo R (2003) Impact of surgical procedure for gastric cancer on quality of life. Br J Surg 90:91-94

40. Buhl K, Lehnert T, Schlag P, Herfarth C (1995) Reconstruction after gastrectomy and quality of life. World J Surg 19:558-564
41. Bae JM, Kim S, Kim YW, Ryu KW, Lee JH, Noh JH, Sohn TS, Hong SK, Park SM, You CH, Kim JH, Lee MK, Yun YH (2006) Health-related quality of life among disease-free stomach cancer survivors in Korea. Qual Life Res 15:1587-1596

42. Huang CC, Lien HH, Wang PC, Yang JC, Cheng CY, Huang CS (2007) Quality of life in disease-free gastric adenocarcinoma survivors: impacts of clinical stages and reconstructive surgical procedures. Dig Surg 24:59-65

43. Lee SS, Ryu SW, Kim IH, Sohn SS (2012) Quality of life beyond the early postoperative period after laparoscopy-assisted distal gastrectomy: the level of patient expectation as the essence of quality of life. Gastric Cancer 15:299-304

44. Tyrvainen T, Sand J, Sintonen H, Nordback I (2008) Quality of life in the long-term survivors after total gastrectomy for gastric carcinoma. J Surg Oncol 97:121-124

45. Nakamura M, Hosoya Y, Yano M, Doki Y, Miyashiro I, Kurashina K, Morooka Y, Kishi K, Lefor AT (2011) Extent of gastric resection impacts patient quality of life: the Dysfunction After Upper Gastrointestinal Surgery for Cancer (DAUGS32) scoring system. Ann Surg Oncol 18:314-320

46. Kong H, Kwon OK, Yu W (2012) Changes of quality of life after gastric cancer surgery. J Gastric Cancer 12:194-200

47. Lee SS, Chung HY, Kwon OK, Yu W (2014) Quality of life in cancer survivors 5 years or more after total gastrectomy: a casecontrol study. Int J Surg (London, England) 12:700-705

48. Lee SS, Chung HY, Yu W (2010) Quality of life of long-term survivors after a distal subtotal gastrectomy. Cancer Res Treat 42:130-134

49. Wenger NK, Mattson ME, Furberg CD, Elinson J (1984) Assessment of quality of life in clinical trials of cardiovascular therapies. Am J Cardiol 54:908-913

50. Ware JE Jr, Kosinski M, Keller SD (1996) A 12-Item Short-Form Health Survey: construction of scales and preliminary tests of reliability and validity. Med Care 34(3):220-233

51. Group E (1990) EuroQol: a new facility for the measurement of health-related quality of life. Health Policy 16:199-208

52. Nieveen Van Dijkum EJ, Terwee CB, Oosterveld P, Van Der Meulen JH, Gouma DJ, De Haes JC (2000) Validation of the gastrointestinal quality of life index for patients with potentially operable periampullary carcinoma. Br J Surg 87:110-115

53. Svedlund J, Sjodin I, Dotevall G (1988) GSRS-a clinical rating scale for gastrointestinal symptoms in patients with irritable bowel syndrome and peptic ulcer disease. Dig Dis Sci 33:129-134 